\title{
Service Hours in Selected Academic Libraries
}

Forty-three state and private university libraries were polled as to the number of hours weekly they remained open, and the reasons for having chosen these hours. The average respondent was open 94.3 hours weekly. Few libraries staying open past 10:00 P.M. give professional staff services in the late evening hours.

M ANY COLLEGE and university libraries are being pressed to remain open into the early morning hours and in some cases to remain open twenty-four hours a day. In order to determine how many hours weekly their libraries were open, a questionnaire was sent recently to forty-three selected state and private universities. Thirty-six questionnaires were returned. The average library in this group stayed open 94.3 hours a week. One stayed open 110 hours a week, while another stayed open only 81 hours a week. The closing time of the libraries is as follows:

$\begin{array}{lc}\text { Closing Time } & \text { Number of Libraries } \\ \text { 10:00 P.M. } & 7 \\ \text { 11:00 P.M. } & 20 \\ \text { 12:00 Midnight } & 7 \\ \text { 1:00 A.M. } & 1 \\ \text { No Information } & \underline{1} \\ \text { Total Libraries } & \underline{36}\end{array}$

The average library in this group served an institution with 8,764 undergraduate students and 2,201 graduate students. It had 619,489 volumes and circulated an average of 21,670 pieces of reading material a month. There were

Mr. Cain is Director of Libraries, Wisconsin State University, Whitewater.
35.8 librarians and 48.1 clerical workers on its staff. Student assistants worked 1,158 hours a week, and $\$ 47,259$ was allocated for student assistant wages.

A second questionnaire was sent to the twenty-eight libraries that were open later than 10:00 P.M., and to the library that gave no information in the first questionnaire about its hours. Twenty-six libraries returned their questionnaires in less than three weeks. Information was also obtained from the University of Wisconsin in Madison and the University of Wisconsin at Milwaukee concerning their library hours.

It was found that in twenty-five libraries librarians do not work after 10:00 P.M., while in only three did they work after 10:00 P.M. It was also found that clerical workers work after 10:00 P.M. in eight libraries and do not work after 10:00 P.M. in seventeen libraries. Student assistants worked in twenty-five libraries after 10:00 P.M. Graduate students only worked in six libraries after 10:00 P.M., while clerical workers worked after this time in seven libraries. One library had only ROTC personnel working after 10:00 P.M., while another library had a sub-professional worker working after this hour.

Security officers worked in seven li- 
braries and did not work in eleven libraries, although they went into the libraries when they made their regular rounds of the campus. Custodians worked in four libraries after 10:00 P.M. Four libraries had two security officers working, while two libraries each had six security officers working. Some of the duties of the security officers were general supervision of reading areas, inspection of the library, closing the library building, and handling disciplinary problems.

Thirteen libraries provided only study space after 10:00 P.M., while seven libraries gave a limited amount of service by student assistants. Some of these seven libraries allowed students to check out reserve reading materials, while one allowed the books in its three small undergraduate reading rooms to be checked out before midnight.

Several that had once remained open later reported that there was not enough use made of the library to justify keeping it open to the early hours of the morning, and have cut their closing hour back to 11:00 P.M. Several reported that they thought students should budget their time better and use the library during the ninety or more hours it was open. Some libraries reported their campuses had many other study areas for students to use between 10:00 P.M. and midnight, such as study rooms in the university centers, church religious centers, dormitories, food centers, and fraternity houses.

Comments seemed to indicate that academic libraries should stay open after 10:00 P.M. only where universities can afford it and where there are enough security officers and student assistants on the library staffs to give adequate supervision. There should also, of course, be enough students using the library facilities to warrant keeping the library open.

On the other hand, academic libraries should not stay open after 10:00 P.M., where there is little use by students and where the universities do not have the money to pay the extra wages of student assistants, the extra salaries of security officers, etc. Some academic institutions encourage students to budget their time and to study and use the library in the early evening hours, when their minds are fresh. Students on some of these campuses have their fraternity, sorority, and other meetings after 10:00 P.M., when their libraries are closed.

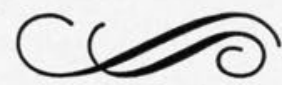

